\title{
Social Media Use for Health Purposes: Systematic Review
}

Junhan Chen, MA; Yuan Wang, MA

Department of Communication, University of Maryland, College Park, MD, United States

Corresponding Author:

Junhan Chen, MA

Department of Communication

University of Maryland

Marie Mount Hall 0401

College Park, MD

United States

Phone: 16085729581

Email: jchen134@umd.edu

\section{Abstract}

Background: Social media has been widely used for health-related purposes, especially during the COVID-19 pandemic. Previous reviews have summarized social media uses for a specific health purpose such as health interventions, health campaigns, medical education, and disease outbreak surveillance. The most recent comprehensive review of social media uses for health purposes, however, was conducted in 2013. A systematic review that covers various health purposes is needed to reveal the new usages and research gaps that emerge in recent years.

Objective: This study aimed to provide a systematic review of social media uses for health purposes that have been identified in previous studies.

Methods: The researchers searched for peer-reviewed journal articles published between 2006 and 2020 in 12 databases covering medicine, public health, and social science. After coding the articles in terms of publication year, journal area, country, method, social media platform, and social media use for health purposes, the researchers provided a review of social media use for health purposes identified in these articles.

Results: This study summarized 10 social media uses for various health purposes by health institutions, health researchers and practitioners, and the public.

Conclusions: Social media can be used for various health purposes. Several new usages have emerged since 2013 including advancing health research and practice, social mobilization, and facilitating offline health-related services and events. Research gaps exist regarding advancing strategic use of social media based on audience segmentation, evaluating the impact of social media in health interventions, understanding the impact of health identity development, and addressing privacy concerns.

(J Med Internet Res 2021;23(5):e17917) doi: 10.2196/17917

\section{KEYWORDS}

social media; health communication; health researchers; health practitioners; health institutions; systematic review

\section{Introduction}

Social media has been widely used in health contexts by various users. For individuals, social media is a primary source of COVID-19 information for patients [1]. Social media is used by $80 \%$ of cancer patients to connect with peers [2]. For health organizations, more than $80 \%$ of US state health departments have social media accounts [3]. Among health professionals, $65 \%$ of radiologists across the United States and Europe use social media for various health-related reasons [4]. A review of the state of the art can provide guidance for practitioners who intend to use social media and for researchers who intend to advance our understanding of social media use for health purposes.

Before reviewing social media use for health purposes, it is necessary to outline the scope of social media and health purposes. Social media has been defined in different ways. Some definitions focus on the technological features of social media that distinguish it from traditional technologies. For example, Kaplan and Haenlein [5] emphasized that social media is a type of application based on the internet and web 2.0 technology. Other definitions focus on the communication features of social media that distinguish it from traditional media. For example, McGowan et al [6] defined social media as an online 
environment where users can contribute to the content and consume content mostly generated by other users. They also emphasized that content being "created by users for users" is an important feature that distinguishes social media from traditional media [6]. From a communication perspective, this paper emphasizes the communication features of social media and considers social media as a web 2.0-based platform for individuals to get access to, share, and generate content. Health purposes include health-related goals such as health promotion, medical service and administration, health research, medical education and training, and health-related social movements. This review focuses on users purposively getting access to, sharing, and generating content on social media in order to achieve various health purposes.

Previous reviews about social media use for health mostly focused on using social media for a single health purpose. These reviews summarized social media as a tool for health interventions [7], health campaigns [8], medical education [9], disease outbreak surveillance [10], and health promotion and behavior change [11]. The most recent comprehensive review of social media use for various health-related purposes was conducted by Moorhead et al [12] and included studies published between 2002 and 2012. However, multiple new uses have emerged between 2013 and 2020 given the rapid development of social media and the need for effective communication and infodemiology practice in the face of emerging health risks. Following Moorhead et al [12], this study reviewed articles published between 2006 and 2020 and categorized social media uses for health purposes in terms of user types, namely, health institutions, health researchers and professionals, and the public. By conducting a systematic review, we aimed to summarize social media use for health purposes, identify new uses that have emerged since 2013 as compared with Moorhead et al [12], and discuss research gaps and future directions for research in social media use for health purposes.

\section{Methods}

\section{Searching Strategy and Inclusion Criteria}

This review followed the PRISMA (Preferred Reporting Items for Systematic Reviews and Meta-analyses) guideline [13] to search and screen articles as shown in Figure 1. In the first step, the researchers searched 12 databases through ProQuest and EBSCO, including important databases in public health, medical, and social science areas such as MEDLINE, Academic Search Complete, PsycINFO, CINAHL, Psychology and Behavioral Science Collection, and Coronavirus Research Database. The search string was "AB(health) AND AB("social media" OR "social network" OR Facebook OR LinkedIn OR Twitter OR Instagram OR Pinterest OR WeChat OR Weibo)." Additional restrictions (ie, published between 2006 and 2020, peer-reviewed scholarly journal article, full text available, and written in English) were added to the search requirement. The time range was set from 2006 to the end of 2020 because most of the current popular social media platforms such as Twitter and Facebook have been created or open to the public since 2006. The initial search retrieved 6293 articles.

In the next step, the two researchers screened items retrieved from the databases. An article was included if the study identifies at least one social media use for health purposes (eg, a study that finds that parents use social media to seek information about breastfeeding), examines the impact of using social media for health purposes (eg, a study that examines the effectiveness of a social media-based health intervention), or explores how to use social media for health purposes (eg, a study that examines how to detect mental health risk through analyzing social media posts). After reviewing the titles, abstracts, and full text, the researchers included 544 articles in the final sample. Articles were excluded for reasons such as not being scholarly journal articles, focusing on the negative health impacts of using social media such as depression and obesity, describing social media networks or social media post characteristics without discussing how to intentionally use social media for health purposes, examining health promotion within an offline social network, or examining social media use in general context rather than health context. 
Figure 1. Article search and screening process.

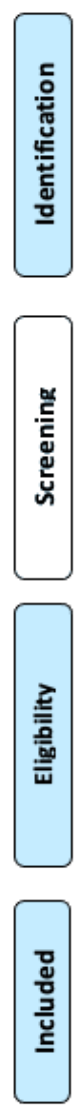

\section{Coding Process}

The preliminary coding scheme was developed by one researcher based on an initial review of $20 \%$ of the articles included. The two researchers coded 20 articles using the preliminary coding scheme and met to discuss the applicability of the preliminary coding categories and possible additional coding categories. The coding scheme was finalized after the two researchers reached an agreement after the discussion. The finalized coding scheme included 8 dimensions: publication year, journal area (eg, public health and medical area, communication, psychology), the country where the study was conducted (eg, United States, United Kingdom, China), type of article (eg, empirical studies, review paper, protocol), methodology used in empirical studies (eg, experiment, survey, interview), type of social media users (ie, health institution, health researcher and professional, publics), and social media use for health purposes. Social media use for health purposes were grouped under social media users. There are 4 usages by health institutions (ie, infoveillance, disseminate health information and combat misinformation, health intervention, and social mobilization), 3 usages by health researchers and professionals (ie, health-related research, professional development, and facilitate doctor-patient communication and offline services), and 3 usages by the public (ie, seek and share health information, exchange social support in an online community, and track and share one's health statuses or activities). The intercoder reliability indicated by Krippendorff alpha ranged from a low of 0.86 to a high of 1.00 . The reliability is satisfactory compared with the 0.80 criterion [14].

\section{Results}

\section{Characteristics of the Studies}

All articles were published between 2016 and 2020. There were 25 articles published in 2016, 42 in 2017, 28 in 2018, 185 in 2019 , and 264 in 2020 . The number of publications continuously increased during the 5 years, showing that social media use for health purposes received growing attention from researchers.

Regarding methodology, most of the articles were empirical studies $(n=399)$. Among the empirical studies, 294 used a quantitative method including experiment, survey, content analysis, and network analysis, and 74 studies used a qualitative method including interview, focus group, and discourse/thematic analysis. There were 15 studies using a mixed method and 16 studies used other methods such as data mining and describing social media metrics of campaign messages (eg, number of likes and views). The rest of the articles were review papers $(n=78)$, commentaries $(n=37)$, protocols $(n=22)$, and theoretical and methodological papers $(n=8)$.

Regarding fields of publication, most articles were published in journals in medical and public health $(n=489)$ followed by journals in communication $(n=26)$, psychology $(n=7)$, sociology $(n=6)$, information science $(n=5)$, interdisciplinary journals $(n=5)$, and journals of other fields $(n=6)$ such as technology, computing, and behavior research method.

Most of the articles featured social media use in the United States $(n=170)$ followed by China $(n=64)$, United Kingdom $(n=20)$, Australia $(n=14)$, Canada $(n=7)$, South Africa $(n=6)$, 
Iran $(n=5)$, Malaysia $(n=4)$, Ghana $(n=4)$, and India $(n=4)$. A total of 43 articles featured social media use in other countries such as Jordan, South Korea, Denmark, and Sweden. Some studies featured social media use in more than one country or internationally $(n=27)$. There were 176 studies that did not specify the geographic scope of social media use. For example, there were studies that analyzed all the English written posts related to a disease on social media or reviewed all the relevant literature about social media-based health intervention.

Regarding the social media platforms used for health purposes, most studies $(n=231)$ examined social media in general without specifying use on certain social media platforms. Other studies featured Twitter $(n=79)$ followed by Facebook $(n=76)$, WeChat $(n=33)$, online forums $(n=16)$, Sina Weibo $(n=13)$, Reddit $(n=8)$, YouTube $(n=8)$, WhatsApp $(n=6)$, Instagram $(n=6)$, and other platforms such as Pinterest, Yelp, and Yahoo! Answer $(n=10)$. There were also 58 studies that featured more than one social media platform.

\section{Social Media Use for Health Purposes}

This review summarized 10 uses of social media for health purposes. Uses were grouped into 3 categories according to the type of social media users, namely, health institution, health researcher and professional, and the public. The following sections summarize social media uses by each type of user and the benefits and challenges related to each use.

\section{Health Institution}

Health institutions include government health agencies and nongovernmental health organizations such as the World Health Organization. The review shows that health institutions mainly used social media for infoveillance $(n=94)$, disseminating health information and combating misinformation $(n=76)$, health intervention $(n=168)$, and social mobilization $(n=7)$.

\section{Infoveillance}

Infoveillance is the application of infodemiology with a primary aim of surveillance, which refers to surveilling and analyzing the unstructured information available on the internet in order to inform public health and public policy [15]. In this review, we focused on the surveillance of information available on social media in order to inform public health. Specifically, articles in this category analyzed social media data to (1) surveil potential public health risks including the onset of individual illnesses and disease outbreaks in a population $(n=70)$ and (2) monitor public responses to health issues $(n=25)$.

First, social media data have been analyzed to predict the future illness onset for individual users. For example, the language used in users' posts such as life stress and anxiety can predict future occurrence of mental illness and distinguish different types of mental illness [16]. In addition, special characters used in social media posts such as emojis can also help identify illness syndromes such as asthma and difficulty breathing syndrome [17]. The use of social media to detect individual illness is especially beneficial for people who are at risk but less motivated to seek diagnosis and treatment; social media surveillance can supplement the traditional doctor-patient interaction method for illness detection [17] and can be combined with social media-based interventions to proactively provide health advice to those who are less likely to seek help [18].

Second, social media data can be analyzed to predict infectious disease outbreaks among a population such as in the COVID-19 outbreak [19]. The studies showed that social media data can provide an accurate prediction of disease outbreak case count [19]. In addition to outbreak prediction, demographic and geographic data obtained from social media can inform medical research and practice of the characteristics of people who are at risk of being infected [20]. Consistent with a recent systematic review of social media-based surveillance systems for health care [21], this study found that Twitter was the most used social media platform for individual illness and disease outbreak surveillance.

Third, user-generated social media posts can provide insights about the public's cognitive and behavioral responses to health-related issues. Studies have analyzed social media posts to understand public concerns and sentiments about ongoing disease outbreaks such as Zika [22] and COVID-19 [23], investigated public attitudes toward and actual implementation of recommended disease prevention actions [20,24], monitored public discussion about controversial health topics such as vaccination [25] and e-cigarettes [26], and gauged public support of health-related policies [27]. Assessing social media data to understand public responses to health issues not only yields results comparable to national survey data but also provides insights for health-related theoretical models [25]. More importantly, traditional public surveys may take weeks and are expensive, while social media provides real-time and inexpensive data to evaluate the effectiveness of public health communication, which allows communication practitioners to adapt timely communication strategies to public needs [23].

\section{Disseminate Health Information and Combat Misinformation}

With the ability to disseminate information quickly and widely, social media can be used by health institutions to post health information and share information with the public. Health institutions can inform the public about common health topics such as healthy living, immunization, and smoking [7]; communicate the risk of disease outbreaks [28]; quickly provide instructions about prevention behaviors to a broad audience during disease outbreaks [29]; and share the latest news and inform the public of the government's handling of disease outbreaks [28,30]. Research efforts have been devoted to exploring strategies for generating health content on social media and increasing retransmission [31,32].

Social media has several advantages over other media outlets when used for disseminating health information. First, social media is seen as the fastest among available channels to share alerts and updates about disease outbreaks [28]. Second, social media allows leveraging various media forms to engage the public. For example, by integrating hyperlinks, social media posts can direct the public to other online resources for additional health information [28,33]. Health institutions can also share podcast audios and YouTube videos on various social media platforms to deliver health information [34,35]. Third, social media can provide a communication platform for 
stakeholders during disease outbreaks. Government social media accounts may become official information sources that provide content about disease outbreaks for local agencies and journalists in a timely manner $[28,33]$.

With the increased volume of misinformation during the COVID-19 pandemic, many studies focused on the concern of rapid misinformation transmission on social media and proposed approaches to combat misinformation through social media. For example, researchers suggested health institutions increase efforts to monitor and enforce fact-checking of dubious information on social media [36,37], promote strategic and timely refutation to misinformation on social media [38], share personal experiences on social media to refute rumors [39], and use search optimization strategies within the social media platforms to redirect users who ask health-related questions to reliable information sources [40]. In addition to combating misinformation through social media, health institutions may also encourage health professionals to establish interpersonal relationships with patients and invite patients to conversations about misinformation that they may encounter online [41]. Although the effectiveness of the approaches proposed by articles in this review have not been formally tested, there have been many studies testing the effectiveness of different message design features in correcting misinformation. For example, Gesser-Edelsburg and colleagues [42] found that a theory-based correction message posted on Facebook by health authorities was more effective in correcting vaccination misinformation than a common correction message. Practitioners may design and post misinformation-correcting messages on social media based on the strategies suggested by these message design studies.

\section{Health Intervention}

Social media has been widely integrated into health interventions and can perform multiple functions. First, social media was used to offer health resources including delivering health information to audiences [43], motivating participation in health-related events [44], and directing campaign audiences and intervention participants to other health resources $[45,46]$. Second, social media was used to support interaction with audience including engaging campaign audiences in 2-way communication with the institutions and health professionals $[47,48]$ and providing platforms for peer support group discussion [49]. Third, social media was used to motivate health behavior change; intervention participants used social media to document and share their own progress of health behavior change such as uploading a picture of an everyday healthy meal [50] and sharing virtual awards of weekly achievement in physical activities [51], setting group challenges toward health goals [52], and engaging in health behavior competition with peers [53]. Last, at the preparing stage of an intervention, social media was also used to reach broader and more varied populations, including hard-to-reach populations [54,55].

Research effort has also focused on improving the design and evaluation of social media-based health interventions. Studies have examined approaches to evaluating campaign outcomes [56], proposed theoretical frameworks for effective health interventions design [57], explored social media user segments to inform intervention development [58], and examined user acceptance and suggestions of receiving social media-based interventions [59]. In general, empirical evidence shows that integrating social media in health interventions is accepted by target populations [59] and effective in increasing health knowledge, reducing risky behaviors, and adopting health behaviors [60]. Researchers have also discussed challenges and raises concerns regarding social media-based health intervention; for example, researchers must rigorously evaluate social media-based interventions throughout the stages of development and implementation, involve populations experiencing health disparities in the studies, and address privacy concerns [61].

\section{Social Mobilization}

Since social media can reach varied stakeholders and a wide audience in society, nongovernmental health organizations can use social media to mobilize social resources. Studies found that these organizations leveraged social media to advocate for change in public policies related to health issues such as HIV/AIDS [62] and mental health [63], raise funds for individual medical care and health-related research [64,65], and raise awareness and promote actions to address health problems such as medical equipment shortages [66]. Although a formal test of the effectiveness of using social media for social mobilization is lacking, the successful cases described in the articles show that social media provides a platform for nongovernmental health organizations to effectively mobilize resources and advocate for collective actions to achieve their goals [62].

\section{Health Researchers and Practitioners}

Social media use by health researchers includes facilitating health-related research $(n=45)$, professional development $(n=34)$, and doctor-patient communication and offline services $(n=36)$.

\section{Facilitate Health-Related Research}

Social media can facilitate health-related research in two ways: provide additional data to learn about patients' disease experience and recruit research participants. First, by analyzing patients' conversations on social media, researchers can gauge patients' understanding of the disease and their coping strategies [67], identify their concerns about the disease [68], understand their barriers to health behavior change [69], identify symptoms related to the disease [70], and assess patients' experience after recovery [71]. Because patient self-reported illness experience is not routinely reported to and recorded by physicians, analyzing patient discussions on social media may enhance health researchers' and professionals' understanding of patient experiences beyond what can be learned from traditional sources of health data [72].

Second, social media can help researchers recruit participants for health-related research. Studies found that social media performs as well as or even better than traditional recruiting methods in terms of cost and number of participants enrolled [73]. Social media is also useful in recruiting hard-to-reach populations such as immigrants [74]. Social media recruitment can generate a representative sample; a study comparing a social media-recruited sample with the underlying population found 
that the sample was representative in 8 of the 13 characteristics studied including demographics and health-related factors [75].

\section{Professional Development}

Health professionals and researchers may use social media for their own professional development such as learning, collaboration, and career advancement. Social media can be used to collaborate on research projects and practices [76], access and share trending research findings and medical knowledge [77,78], broaden their exposure to funders and publishers [79], conduct a job search [80], follow medical conferences remotely [81], market their team and services, and discuss interesting or difficult cases with colleagues [4]. Studies found that different social media platforms serve different roles in the professional development of health professionals and researchers; Pinterest was mostly used for health care-quality education [82], Twitter for gathering news and information on conferences, and LinkedIn for career advancement [81]. Nearly $85 \%$ of health professionals agreed that social media can be an effective tool for educational purposes [82], and $71 \%$ of health professionals, researchers, and businesspeople in the urology discipline agreed that social media is useful for career development [83].

\section{Facilitate Doctor-Patient Communication and Offline Health Services}

Health professionals use social media for doctor-patient communication including responding to questions posted by patients [84], offering online consultation [85], and proactively providing advice and health information to social media followers [86]. In addition, social media can be used to support offline health services. Health professionals can use social media to inform patients of the results of their examination [4], encourage compliance with medication [87], receive feedback from patients about their health services [4], and collect information from patients after discharge to inform future practices [88]. Encouraging interactions between health practitioners and patients on social media may benefit both patients' well-being and patient-physician relationships [89]. In addition, social media can also be used to provide medical services such as appointments, medical inquiries, personal information management, and medical charge payment, which can increase the accessibility of medical care and improve patient experiences [90].

However, increasing use of social media by health professionals and researchers is accompanied by concerns and challenges. Many studies raised concerns about risks to patients' privacy and confidentiality [80] and health professionals lacking knowledge about social media [4]. Studies also discussed challenges such as protecting content generators' intellectual property [91] and managing negative comments from patients [4]. Most of these articles called for developing a guideline or a regulation regarding ethical, legal, and technological issues $[4,80]$ and providing training for health professionals and researchers on the proper use of social media [91,92].

\section{Public}

The public includes healthy people and those with health concerns, including patients with known diagnoses and populations at risk of certain health problems, such as men who have sex with men, first-time pregnant mothers, and LGBTQIA+ (lesbian, gay, bisexual, transgender, queer, intersex, asexual) youth. The reviews show that the public uses social media to seek and share health-related information $(n=108)$, exchange social support in online communities $(n=95)$, and track and share health statuses or activities $(n=10)$.

\section{Seek and Share Health-Related Information}

Seeking and sharing health information is the most common use by the public. The public uses social media to follow and share news about trending health issues such as flu [93] and COVID-19 [1], find information on daily health behaviors such as fitness and healthy food choices [94-96], search for health advice for their own health concern such as pregnancy-related information [97], request a crowd diagnosis or second opinion after seeing a health care professional about their illness [98], access health care law [70], follow social media accounts of health organizations and professionals $[99,100]$, and learn about physicians and hospitals to inform their choices [101]. Social media has become a primary information source for the public with varying information needs [1,102].

However, many studies raised concerns of social media information quality and its impact on individual health outcomes [103]. Indeed, empirical studies provided grounds for the concern. Sallam et al [104] found that people who relied on social media for health information had a lower COVID-19 knowledge score compared with those who relied on doctors and scientific journals for information. In addition, people who sought information on social media did not confirm its accuracy with health professionals, and health professionals disagreed with the information found on social media on $36.7 \%$ of occasions when people checked the information accuracy with health professionals [105]. This evidence calls for efforts to reduce misinformation on social media and improve the ability of the public to find reliable information sources on social media.

\section{Exchange Social Support in Online Communities}

Social support includes informational support, emotional support, esteem support, network support, and tangible support [106]. Except for tangible support, other types of social support were widely found in interactions in the online health community.

People with certain health concerns can receive and provide informational support content. They may read the experience of others diagnosed with the same illness, share details of their own medication and diagnosis [107,108], share and access medical knowledge such as treatment options and self-care activities [109], learn about health laws [110], and solicit recommendations of doctors and hospitals [99]. They may also proactively request health information and advice [111] and validate health information with others [112].

Emotional and esteem support, expressions that convey love and caring (emotional support) and respect and confidence in ability (esteem support), were considered as one category [106]. People with health concerns may express their disease feelings to mitigate their stress and appeal for sympathy [113], offer 
hope and a sense of empowerment to each other [114], and encourage peers' engagement in medical care [115].

Network support content refers to expressions that communicate belonging to a group of people who have the same concerns or interest [106]: individual users use social media to build community with people who have similar health concerns or health goals [116], foster a group identity [116], enhance a sense of belonging [117], achieve shared health goals together [118], get connected with peer patients [119], and get involved in social events such as swimming lessons with peers [120]. Network support also empowered people with health concerns to influence health awareness at the societal level such as raising awareness of queer and trans issues [121].

People with health concerns may benefit from participating in online communities in several ways. First, they do not have to reveal personal identity and thus are free from the risk of being stigmatized when participating in online communities [107]. Second, online communities as an information channel supplement offline communication channels in terms of content and time. Peers may provide more information on treatment options not raised by health professionals because of time constraints [109]. Also, people can get answers and emotional support from online communities 24/7, while other social networks may not be able to provide such timely support [122]. Third, people have a sense of control over the help-seeking process when participating in online communities, which may fulfill patients' need of autonomy and reduce treatment avoidance [123]. Last, engaging in online communities may benefit health outcomes; studies found that perceived social support predicted subjective well-being [124].

\section{Track and Share Health Statuses or Activities}

Social media enables users to track and share their health statuses or activities and view those of others in the community. The public can document and share their illness experiences such as a breast cancer journey [125] or experience with chronic disease [126], achievements in health behavior change [127], and fitness activities [128] such as cycling and walking [129]. By self-tracking and sharing their physical activities, users can build networks with other users and discuss their activity performances [129]. Writing about and sharing their illness experiences may help patients cope with illness [125] and achieve health goals [126]. Other users may also benefit from such sharing as they can easily find peers who have similar experience to get advice on lifestyle changes and discuss treatment options [130].

\section{Discussion}

We reviewed articles published between 2006 and 2020 and identified 10 uses of social media for health purposes. The review found new social media uses for health purposes that emerged after 2013 as well as research gaps that need future research. The following sections will discuss the new uses and gaps.

\section{New Social Media Uses for Health Purposes}

Several new usages have emerged since 2013 compared with the usages summarized by Moorhead et al [12]. First, recent studies have begun to explore social media use for health purposes beyond the scope of patients, the general public, and health professionals. Studies have paid attention to social media use by health institutions including government agencies such as US federal, state, and local health departments [3,28,131] and nongovernmental health organizations [62]. Social media use identified in Moorhead et al [12] mostly benefits individuals who are experiencing illness or with the need for health information, while the use of social media by government agencies may benefit the whole society, especially during disease outbreaks. These articles also mentioned the limitations of government agencies using social media for health purposes such as lack of conversation with the public [131] and a disconnect between the health-related content generated by government agencies on social media and the actual health conditions that affect the population [2].

Second, studies in recent years have started to pay attention to social media use by health professionals and researchers to advance their practices and research. Social media is not only a communication channel that facilitates their conversation with patients [85] but also a tool for professional development [132] and health-related research [75]. Social media can provide opportunities for professional development from job searches to learning about trending research findings $[77,80]$. In addition, although studies have long been using social media for recruitment as a research tool, research efforts have been made to investigate the effectiveness of using social media for recruitment in recent years (ie, 2019-2020) and found social media promising as a recruitment tool [75].

Third, studies in recent years have found that social media can be used for social mobilization. Social media provides new opportunities for nongovernmental organizations to build community, mobilize resources, and extend discourse about sensitive issues beyond mainstream media coverage [47]. Although social mobilization was often initiated by nonprofit health organizations, people with heath concerns can form a community and collectively use social media to raise awareness of a disease or minority population. For example, patients with brain injuries can use social media to increase awareness of brain injury in society [133]. Social media was also used by LGBTQIA+ youth in the United States to increase the visibility of that population's voice and promote civic engagement on public issues related to the population [121].

Last, as social media incorporates more functions such as sending reminders, registering for events, and linking payment methods, social media becomes useful in facilitating offline health-related services and events such as making appointments and providing visiting guides [90]. In this sense, social media not only serves as a communication tool but also a tool for medical service and administration. However, this emerging usage may not be applicable to all social media platforms, as different platforms may incorporate functions not suitable for administrative uses. Moreover, this usage poses challenges to health organizations as they need to concern about the privacy issue and the need of additional workforces to manage their social media accounts [90]. 


\section{Research Gaps in Social Media Uses for Health Purposes}

There are several gaps existing in this research on using social media for health purposes. First, future studies should explore and test strategies to motivate engagement based on evidence of audience segmentation. There have been research efforts devoted to examining the audience segments on social media based on network characteristics in a health campaign [58], the extent to which users produce and consume health-related user-generated content [134], and users' motivation for participating in an online community [135]. Although these studies on audience segmentation provide implications on strategies to engage different types of audiences, we need more studies to formally test the effectiveness of strategies derived from audience segmentation research.

In addition, future research should develop a dynamic audience segment-detecting tool that can monitor audience characteristics and integrate these characteristics to predict audience segments on social media. Multiple factors may collaboratively determine audience types such as offline support [134], sentiment about the health issue [58], illness stage, need for support [135], and availability of spare time [136]. Some of these factors may change over time resulting in a transitioning of audience types [135]. As a result, changes in social media users' health status and social environments may lead to changes in their engagement pattern on social media. By predicting the change in user engagement patterns, practitioners can develop tailored engagement strategies for different types of social media users and adapt the strategies according to individual changes as an intervention goes on.

Second, more studies are needed exploring the relative impact of different applications of social media in health interventions on health outcomes, a research gap identified by Moorhead et al [12] that remains unresolved. Although the general impact of integrating social media in health interventions on promoting health knowledge and behavior is promising, it is unclear if different uses of social media in health interventions have different impacts. Social media can be integrated into an intervention in multiple ways and used for peer discussion with or without discussion leaders [137], conversations between participants and health professionals [138], delivering real-time and adaptive intervention messages [139] or regular intervention messages [45], delivering information in texts or more attractive formats such as video and infographics [138], intervention monitors to acknowledge achievements in participant health behavior changes [51], or participants to share their achievements with each other [127], etc. Using social media in these different manners may result in different effects on participant health behaviors and outcomes. For example, Garett et al [140] found that participants in the intervention group (ie, a Facebook group with peer leaders) acquired more knowledge about sexual health services and felt more comfortable with connecting with peers than those in the control group (ie, a Facebook group without peer leaders). Experimental studies and meta-analyses may be helpful to examine if and how using social media in an intervention in different ways affect health behavior change differently.
Third, social media enables users with similar health issues to develop health-related identities in a community. However, under which conditions identity building leads to positive or negative health behaviors and health outcomes is unclear [141]. Although developing identities may foster mutual support and decrease a sense of isolation [116], building an identity with a certain patient group can reinforce negative health behaviors such as disordered eating behaviors [142], and being part of a healthy community may pose pressures for users to consistently present an optimal identity as a healthy role model under persistent self- and community surveillance [128]. Researchers should explore approaches to using the identity-building function of social media to improve health outcomes and avoid negative impacts.

Last, privacy concerns were raised in articles on using social media for various health purposes including disease surveillance [21], health interventions [60], participation in online communities [143], and professionals communicating with colleagues and patients [76]. Researchers have consistently called for efforts to address privacy concerns related to using social media for health purposes $[12,61,144]$. Indeed, research effort has been made such as developing models to filter patients and caregivers and match them with trusted peer patients and caregivers in a privacy-preserving way [85] and developing social media privacy guide for health professionals [145]. However, gaps still exist in research and practice such as lacking an official guideline about privacy issues related to using social media in health research recruitment $[73,146]$, lacking an approach to guarantee online informed consent [140], and researchers and potential participants lacking the awareness of the privacy risks of social media research recruitment [146]. Future studies should explore research methods and form practice guidelines that can address privacy issues associated with using social media for health research, intervention, and patient-doctor interaction.

\section{Limitations}

The review has several limitations. First, the review does not include conference papers, dissertations, and grey literature. However, given the large number of peer-reviewed journal articles included in the review and overlaps on social media uses identified in the articles, we expect that there will not be many other social media uses left unidentified by the review.

Second, we only searched keywords in abstracts instead of full texts. This may render the review missing articles that mentioned social media uses for health purposes only in the main text and not in the abstract. Indeed, some articles were not included in this review but were included in previous reviews; all articles included in this study were published between 2016 and 2020, while the previous review conducted by Moorhead and colleagues [12] included articles published before 2013. However, although the scope of this review may be limited due to the restrictive search strategy, the uses identified in the review cover most social media uses found by Moorhead and colleagues [12], meaning this study provides a comprehensive overview of the social media uses identified in existing literature. In addition, this review contributes to the literature by identifying social media uses for health purposes emerging after 2013. 


\section{Conclusions}

This review summarized 10 social media uses for health purposes identified in previous literature and categorized the social media uses in terms of user types. Public health practitioners and organizations may use the summary as a starting point to explore applying social media in their daily practice. In addition, the review contributes to the literature by identifying research gaps in social media use for health purposes, providing guidance for future research in this area.

\section{Conflicts of Interest}

None declared.

\section{References}

1. Zhong Y, Liu W, Lee T, Zhao H, Ji J. Risk perception, knowledge, information sources and emotional states among COVID-19 patients in Wuhan, China. Nurs Outlook 2020 Aug 22;69(1):13-21 [FREE Full text] [doi: 10.1016/j.outlook.2020.08.005] [Medline: $\underline{32980153]}$

2. Braun LA, Zomorodbakhsch B, Keinki C, Huebner J. Information needs, communication and usage of social media by cancer patients and their relatives. J Cancer Res Clin Oncol 2019 Jul;145(7):1865-1875 [FREE Full text] [doi: 10.1007/s00432-019-02929-9] [Medline: 31123824 ]

3. Jha A, Lin L, Savoia E. The use of social media by state health departments in the US: analyzing health communication through Facebook. J Community Health 2016 Feb;41(1):174-179. [doi: 10.1007/s10900-015-0083-4] [Medline: 26318742]

4. Ranschaert ER, Van Ooijen PMA, McGinty GB, Parizel PM. Radiologists' usage of social media: results of the RANSOM survey. J Digit Imaging 2016 Aug;29(4):443-449 [FREE Full text] [doi: 10.1007/s10278-016-9865-1] [Medline: 26847202]

5. Kaplan A, Haenlein M. Users of the world, unite! The challenges and opportunities of social media. Bus Horizons 2010 Jan;53(1):59-68 [FREE Full text] [doi: 10.1016/j.bushor.2009.09.003]

6. McGowan BS, Wasko M, Vartabedian BS, Miller RS, Freiherr DD, Abdolrasulnia M. Understanding the factors that influence the adoption and meaningful use of social media by physicians to share medical information. J Med Internet Res 2012;14(5):e117 [FREE Full text] [doi: 10.2196/jmir.2138] [Medline: 23006336]

7. Yang Q. Are social networking sites making health behavior change interventions more effective? A meta-analytic review. J Health Commun 2017 Mar;22(3):223-233. [doi: 10.1080/10810730.2016.1271065] [Medline: 28248623]

8. Shi J, Poorisat T, Salmon CT. The use of social networking sites (SNSs) in health communication campaigns: review and recommendations. Health Commun 2018 Jan;33(1):49-56 [FREE Full text] [doi: 10.1080/10410236.2016.1242035] [Medline: 27858464]

9. Cheston CC, Flickinger TE, Chisolm MS. Social media use in medical education: a systematic review. Acad Med 2013 Jun;88(6):893-901. [doi: 10.1097/ACM.0b013e31828ffc23] [Medline: 23619071]

10. Charles-Smith LE, Reynolds TL, Cameron MA, Conway M, Lau EHY, Olsen JM, et al. Using social media for actionable disease surveillance and outbreak management: a systematic literature review. PLoS One 2015;10(10):e0139701 [FREE Full text] [doi: 10.1371/journal.pone.0139701] [Medline: 26437454]

11. Korda H, Itani Z. Harnessing social media for health promotion and behavior change. Health Promot Pract 2013 Jan;14(1):15-23. [doi: 10.1177/1524839911405850] [Medline: 21558472]

12. Moorhead SA, Hazlett DE, Harrison L, Carroll JK, Irwin A, Hoving C. A new dimension of health care: systematic review of the uses, benefits, and limitations of social media for health communication. J Med Internet Res 2013;15(4):e85 [FREE Full text] [doi: 10.2196/jmir.1933] [Medline: 23615206]

13. Moher D, Liberati A, Tetzlaff J, Altman DG. Preferred reporting items for systematic reviews and meta-analyses: the PRISMA statement. PLoS Med 2009 Jul 21;6(7):e1000097 [FREE Full text] [doi: 10.1371/journal.pmed.1000097] [Medline: 19621072]

14. Krippendorff K. Reliability in content analysis: some common misconceptions and recommendations. Human Comm Res 2004 Jul 01;30(3):411-433 [FREE Full text] [doi: 10.1093/hcr/30.3.411]

15. Eysenbach G. Infodemiology and infoveillance: framework for an emerging set of public health informatics methods to analyze search, communication and publication behavior on the Internet. J Med Internet Res 2009;11(1):e11 [FREE Full text] [doi: 10.2196/jmir.1157] [Medline: 19329408]

16. Thorstad R, Wolff P. Predicting future mental illness from social media: a big-data approach. Behav Res Methods 2019 Aug;51(4):1586-1600 [FREE Full text] [doi: 10.3758/s13428-019-01235-z] [Medline: 31037606]

17. Edo-Osagie O, Smith G, Lake I, Edeghere O, De La Iglesia B. Twitter mining using semi-supervised classification for relevance filtering in syndromic surveillance. PLoS One 2019;14(7):e0210689 [FREE Full text] [doi: 10.1371/journal.pone.0210689] [Medline: $\underline{31318885]}$

18. Liu X, Liu X, Sun J, Yu NX, Sun B, Li Q, et al. Proactive Suicide Prevention Online (PSPO): machine identification and crisis management for chinese social media users with suicidal thoughts and behaviors. J Med Internet Res 2019 May 08;21(5):e11705 [FREE Full text] [doi: 10.2196/11705] [Medline: $\underline{\text { 31344675] }}$ 
19. Shen C, Chen A, Luo C, Zhang J, Feng B, Liao W. Using reports of symptoms and diagnoses on social media to predict COVID-19 case counts in mainland China: observational infoveillance study. J Med Internet Res 2020 May 28;22(5):e19421 [FREE Full text] [doi: 10.2196/19421] [Medline: 32452804]

20. Huang X, Li Z, Jiang Y, Li X, Porter D. Twitter reveals human mobility dynamics during the COVID-19 pandemic. PLoS One 2020;15(11):e0241957 [FREE Full text] [doi: 10.1371/journal.pone.0241957] [Medline: 33170889]

21. Gupta A, Katarya R. Social media based surveillance systems for healthcare using machine learning: a systematic review. J Biomed Inform 2020 Aug;108:103500 [FREE Full text] [doi: 10.1016/j.jbi.2020.103500] [Medline: 32622833]

22. Zhang J, Chen Y, Zhao Y, Wolfram D, Ma F. Public health and social media: a study of Zika virus - related posts on Yahoo! Answers. J Assoc Inf Sci Technol 2019 May 17;71(3):282-299 [FREE Full text] [doi: 10.1002/asi.24245]

23. Hung M, Lauren E, Hon ES, Birmingham WC, Xu J, Su S, et al. Social network analysis of COVID-19 sentiments: application of artificial intelligence. J Med Internet Res 2020 Aug 18;22(8):e22590 [FREE Full text] [doi: 10.2196/22590] [Medline: $\underline{32750001]}$

24. Doogan C, Buntine W, Linger H, Brunt S. Public perceptions and attitudes toward COVID-19 nonpharmaceutical interventions across six countries: a topic modeling analysis of twitter data. J Med Internet Res 2020 Sep 03;22(9):e21419 [FREE Full text] [doi: 10.2196/21419] [Medline: $\underline{\text { 32784190] }}$

25. Zhang H, Wheldon C, Dunn AG, Tao C, Huo J, Zhang R, et al. Mining Twitter to assess the determinants of health behavior toward human papillomavirus vaccination in the United States. J Am Med Inform Assoc 2020 Feb 01;27(2):225-235 [RREE Full text] [doi: 10.1093/jamia/ocz191] [Medline: $\underline{31711186]}$

26. Eden OB, Lilleyman J, Shaw MP, Richards S, Peto J. Medical Research Council Childhood Leukaemia Trial VIII compared with trials II-VII: lessons for future management. Haematol Blood Transfus 1987;30:448-455 [FREE Full text] [doi: 10.1007/978-3-642-71213-5 79] [Medline: 3305212]

27. Hatchard JL, Quariguasi Frota Neto J, Vasilakis C, Evans-Reeves KA. Tweeting about public health policy: social media response to the UK Government's announcement of a Parliamentary vote on draft standardised packaging regulations. PLoS One 2019;14(2):e0211758 [FREE Full text] [doi: 10.1371/journal.pone.0211758] [Medline: $\underline{30807582}$ ]

28. Jin Y, Austin L, Vijaykumar S, Jun H, Nowak G. Communicating about infectious disease threats: insights from public health information officers. Public Relations Rev 2019 Mar;45(1):167-177 [FREE Full text] [doi: 10.1016/j.pubrev.2018.12.003]

29. Vandormael A, Adam M, Greuel M, Bärnighausen T. An entertainment-education approach to prevent COVID-19 spread: study protocol for a multi-site randomized controlled trial. Trials 2020 Dec 15;21(1):1025 [FREE Full text] [doi: 10.1186/s13063-020-04942-7] [Medline: 33323130]

30. Chen Q, Min C, Zhang W, Wang G, Ma X, Evans R. Unpacking the black box: how to promote citizen engagement through government social media during the COVID-19 crisis. Comput Human Behav 2020 Sep;110:106380 [FREE Full text] [doi: 10.1016/j.chb.2020.106380] [Medline: 32292239]

31. Sutton J, Renshaw SL, Butts CT. COVID-19: retransmission of official communications in an emerging pandemic. PLoS ONE 2020 Sep 16;15(9):e0238491 [FREE Full text] [doi: 10.1371/journal.pone.0238491]

32. Gatewood J, Monks SL, Singletary CR, Vidrascu E, Moore JB. Social media in public health: strategies to distill, package, and disseminate public health research. J Public Health Manag Pract 2020;26(5):489-492 [FREE Full text] [doi: 10.1097/PHH.0000000000001096] [Medline: 32732723]

33. McInnes C, Hornmoen H. Add Twitter and Stir: the use of Twitter by public authorities in Norway and UK during the 2014-15 Ebola outbreak. Observatorio 2018;12(2):23-46 [FREE Full text] [doi: 10.15847/obsobs12220181173]

34. Harrison D, Wilding J, Bowman A, Fuller A, Nicholls SG, Pound CM, et al. Using YouTube to disseminate effective vaccination pain treatment for babies. PLoS One 2016;11(10):e0164123 [FREE Full text] [doi: 10.1371/journal.pone.0164123] [Medline: 27695054]

35. Patrick MD, Stukus DR, Nuss KE. Using podcasts to deliver pediatric educational content: development and reach of PediaCast CME. Digit Health 2019;5:2055207619834842 [FREE Full text] [doi: 10.1177/2055207619834842] [Medline: 30834137]

36. Grimes DR. EMBO Rep 2020 Nov 05;21(11):e51819 [FREE Full text] [doi: 10.15252/embr.202051819] [Medline: 33155436]

37. Xie T, Tan T, Li J. An extensive search trends-based analysis of public attention on social media in the early outbreak of COVID-19 in China. Risk Manag Healthc Policy 2020;13:1353-1364 [FREE Full text] [doi: 10.2147/RMHP.S257473] [Medline: 32943953]

38. Steffens MS, Dunn AG, Wiley KE, Leask J. How organisations promoting vaccination respond to misinformation on social media: a qualitative investigation. BMC Public Health 2019 Oct 23;19(1):1348 [FREE Full text] [doi: 10.1186/s12889-019-7659-3] [Medline: $\underline{\text { 31640660] }}$

39. Mheidly N, Fares J. Leveraging media and health communication strategies to overcome the COVID-19 infodemic. J Public Health Policy 2020 Dec;41(4):410-420 [FREE Full text] [doi: 10.1057/s41271-020-00247-w] [Medline: 32826935]

40. Cuello-Garcia C, Pérez-Gaxiola G, van Amelsvoort L. Social Media can have an impact on how we manage and investigate the COVID-19 pandemic. J Clin Epidemiol 2020 Jun 27:127-201 [FREE Full text] [doi: 10.1016/j.jclinepi.2020.06.028] [Medline: $\underline{\text { 32603686] }}$ 
41. Southwell BG, Wood JL, Navar AM. Roles for health care professionals in addressing patient-held misinformation beyond fact correction. Am J Public Health 2020 Oct;110(S3):S288-S289 [FREE Full text] [doi: 10.2105/AJPH.2020.305729] [Medline: $\underline{33001723}$ ]

42. Gesser-Edelsburg A, Diamant A, Hijazi R, Mesch GS. Correcting misinformation by health organizations during measles outbreaks: a controlled experiment. PLoS One 2018;13(12):e0209505 [FREE Full text] [doi: 10.1371/journal.pone.0209505] [Medline: 30566485]

43. Diddi P, Lundy LK. Organizational Twitter use: content analysis of tweets during breast cancer awareness month. J Health Commun 2017 Dec;22(3):243-253. [doi: 10.1080/10810730.2016.1266716] [Medline: 28248621]

44. Li H, Xue L, Tucker JD, Wei C, Durvasula M, Hu W, et al. Condom use peer norms and self-efficacy as mediators between community engagement and condom use among Chinese men who have sex with men. BMC Public Health 2017 Aug 07;17(1):641 [FREE Full text] [doi: 10.1186/s12889-017-4662-4] [Medline: 28784172]

45. Ashton LM, Morgan PJ, Hutchesson MJ, Rollo ME, Collins CE. Feasibility and preliminary efficacy of the 'HEYMAN' healthy lifestyle program for young men: a pilot randomised controlled trial. Nutr J 2017 Jan 13;16(1):2 [FREE Full text] [doi: 10.1186/s12937-017-0227-8] [Medline: 28086890]

46. Payton F. Cultures of participation-for students, by students. Info Systems J 2015 Aug 14;26(4):319-338 [FREE Full text] [doi: $10.1111 /$ isj.12086]

47. Chung JE. A smoking cessation campaign on Twitter: understanding the use of Twitter and identifying major players in a health campaign. J Health Commun 2016 May;21(5):517-526. [doi: 10.1080/10810730.2015.1103332] [Medline: 27115179]

48. Park H, Reber BH, Chon M. Tweeting as health communication: health organizations' use of Twitter for health promotion and public engagement. J Health Commun 2016;21(2):188-198. [doi: 10.1080/10810730.2015.1058435] [Medline: 26716546]

49. Yu Y, Li Y, Li T, Xi S, Xiao X, Xiao S, et al. New path to recovery and well-being: cross-sectional study on Wechat use and endorsement of Wechat-based mHealth among people living with schizophrenia in China. J Med Internet Res 2020 Sep 18;22(9):e18663 [FREE Full text] [doi: 10.2196/18663] [Medline: 32945774]

50. Fernandez-Luque L, Singh M, Ofli F, Mejova YA, Weber I, Aupetit M, et al. Implementing $360^{\circ}$ Quantified Self for childhood obesity: feasibility study and experiences from a weight loss camp in Qatar. BMC Med Inform Decis Mak 2017 Apr 13;17(1):37 [FREE Full text] [doi: 10.1186/s12911-017-0432-6] [Medline: 28403865]

51. Mendoza JA, Baker KS, Moreno MA, Whitlock K, Abbey-Lambertz M, Waite A, et al. A Fitbit and Facebook mHealth intervention for promoting physical activity among adolescent and young adult childhood cancer survivors: a pilot study. Pediatr Blood Cancer 2017 Dec;64(12):1. [doi: 10.1002/pbc.26660] [Medline: 28618158]

52. Chung AE, Skinner AC, Hasty SE, Perrin EM. Tweeting to health: a novel mHealth intervention using Fitbits and Twitter to foster healthy lifestyles. Clin Pediatr (Phila) 2016 Jun 16;56(1):26-32. [doi: 10.1177/0009922816653385] [Medline: 27317609]

53. Fang Y, Ma Y, Mo D, Zhang S, Xiang M, Zhang Z. Methodology of an exercise intervention program using social incentives and gamification for obese children. BMC Public Health 2019 Jun 03;19(1):686 [FREE Full text] [doi:

10.1186/s12889-019-6992-x] [Medline: $\underline{\text { 31159776] }}$

54. Pagkas-Bather J, Young LE, Chen Y, Schneider JA. Social network interventions for HIV transmission elimination. Curr HIV/AIDS Rep 2020 Oct;17(5):450-457 [FREE Full text] [doi: 10.1007/s11904-020-00524-z] [Medline: 32720253]

55. Thornber K, Huso D, Rahman MM, Biswas H, Rahman MH, Brum E, et al. Raising awareness of antimicrobial resistance in rural aquaculture practice in Bangladesh through digital communications: a pilot study. Glob Health Action 2019;12(sup1):1734735 [FREE Full text] [doi: 10.1080/16549716.2020.1734735] [Medline: $\underline{32153258]}$

56. Chan L, O'Hara B, Phongsavan P, Bauman A, Freeman B. Review of evaluation metrics used in digital and traditional tobacco control campaigns. J Med Internet Res 2020 Aug 11;22(8):e17432 [FREE Full text] [doi: 10.2196/17432] [Medline: 32348272]

57. Moreno MA, D'Angelo J. Social media intervention design: applying an affordances framework. J Med Internet Res 2019 Mar 26;21(3):e11014 [FREE Full text] [doi: 10.2196/11014] [Medline: 30912754]

58. Chu K, Allem J, Unger JB, Cruz TB, Akbarpour M, Kirkpatrick MG. Strategies to find audience segments on Twitter for e-cigarette education campaigns. Addict Behav 2019 Apr;91:222-226 [FREE Full text] [doi: 10.1016/j.addbeh.2018.11.015] [Medline: 30497815]

59. Xiao S, Li T, Zhou W, Shen M, Yu Y. WeChat-based mHealth intention and preferences among people living with schizophrenia. PeerJ 2020;8:e10550 [FREE Full text] [doi: 10.7717/peerj.10550] [Medline: $\underline{33362979]}$

60. Ronen K, Grant E, Copley C, Batista T, Guthrie BL. Peer group focused ehealth strategies to promote HIV prevention, testing, and care engagement. Curr HIV/AIDS Rep 2020 Oct;17(5):557-576 [FREE Full text] [doi: 10.1007/s11904-020-00527-w] [Medline: 32794071]

61. Bakken S, Marden S, Arteaga SS, Grossman L, Keselman A, Creber RM, et al. Behavioral interventions using consumer information technology as tools to advance health equity. Am J Public Health 2019 Jan;109(S1):S79-S85. [doi: 10.2105/AJPH.2018.304646] [Medline: 30699018]

62. Fu J, Zhang R. NGOs' HIV/AIDS discourse on social media and websites: technology affordances and strategic communication across media platforms. Int J Comm 2019;13:25. 
63. Sinnenberg L, Buttenheim AM, Padrez K, Mancheno C, Ungar L, Merchant RM. Twitter as a tool for health research: a systematic review. Am J Public Health 2017 Dec;107(1):e1-e8. [doi: 10.2105/AJPH.2016.303512] [Medline: 27854532]

64. Ren J, Raghupathi V, Raghupathi W. Understanding the dimensions of medical crowdfunding: a visual analytics approach. J Med Internet Res 2020 Jul 03;22(7):e18813 [FREE Full text] [doi: 10.2196/18813] [Medline: 32618573]

65. Young MJ, Scheinberg E. The rise of crowdfunding for medical care: promises and perils. JAMA 2017 Apr 25;317(16):1623-1624 [FREE Full text] [doi: 10.1001/jama.2017.3078] [Medline: 28334321]

66. He S, Ojo A, Beckman AL, Gondi S, Gondi S, Betz M, et al. The story of \#GetMePPE and GetUsPPE.org to mobilize health care response to COVID-19: rapidly deploying digital tools for better health care. J Med Internet Res 2020 Jul 20;22(7):e20469 [FREE Full text] [doi: 10.2196/20469] [Medline: 32530813]

67. Guidry J, Zhang Y, Jin Y, Parrish C. Portrayals of depression on Pinterest and why public relations practitioners should care. Public Relations Rev 2016 Mar;42(1):232-236 [FREE Full text] [doi: 10.1016/j.pubrev.2015.09.002]

68. Jiang T, Osadchiy V, Mills JN, Eleswarapu SV. Is it all in my head? Self-reported psychogenic erectile dysfunction and depression are common among young men seeking advice on social media. Urology 2020 May 11;142:133-140. [doi: 10.1016/j.urology.2020.04.100] [Medline: 32437776]

69. Oser TK, Minnehan KA, Wong G, Parascando J, McGinley E, Radico J, et al. Using social media to broaden understanding of the barriers and facilitators to exercise in adults with type 1 diabetes. J Diabetes Sci Technol 2019 May;13(3):457-465. [doi: 10.1177/1932296819835787] [Medline: 30862185]

70. Erikainen S, Pickersgill M, Cunningham-Burley S, Chan S. Patienthood and participation in the digital era. Digit Health 2019;5:2055207619845546 [FREE Full text] [doi: 10.1177/2055207619845546] [Medline: 31041112]

71. Koutrolou-Sotiropoulou P, Lima FV, Stergiopoulos K. Quality of life in survivors of peripartum cardiomyopathy. Am J Cardiol 2016 Jul 15;118(2):258-263 [FREE Full text] [doi: 10.1016/j.amjcard.2016.04.040] [Medline: 27239023]

72. McDonald L, Malcolm B, Ramagopalan S, Syrad H. Real-world data and the patient perspective: the PROmise of social media? BMC Med 2019 Jan 16;17(1):11 [FREE Full text] [doi: 10.1186/s12916-018-1247-8] [Medline: $\underline{30646913}$ ]

73. Sanchez C, Grzenda A, Varias A, Widge AS, Carpenter LL, McDonald WM, et al. Social media recruitment for mental health research: a systematic review. Compr Psychiatry 2020 Nov;103:152197 [FREE Full text] [doi: 10.1016/j.comppsych.2020.152197] [Medline: $\underline{\text { 32992073] }}$

74. Cudjoe J, Turkson-Ocran R, Ezeigwe AK, Commodore-Mensah Y, Nkimbeng M, Han H. Recruiting African immigrant women for community-based cancer prevention studies: lessons learned from the AfroPap Study. J Community Health 2019 Oct;44(5):1019-1026. [doi: 10.1007/s10900-019-00677-y] [Medline: 31102117]

75. Shaver LG, Khawer A, Yi Y, Aubrey-Bassler K, Etchegary H, Roebothan B, et al. Using Facebook advertising to recruit representative samples: feasibility assessment of a cross-sectional survey. J Med Internet Res 2019 Aug 19;21(8):e14021 [FREE Full text] [doi: 10.2196/14021] [Medline: $\underline{\text { 31429409] }}$

76. Cherrez-Ojeda I, Vanegas E, Felix M, Mata VL, Jiménez FM, Sanchez M, et al. Frequency of use, perceptions and barriers of information and communication technologies among Latin American physicians: an Ecuadorian cross-sectional study. J Multidiscip Healthc 2020;13:259-269 [FREE Full text] [doi: 10.2147/JMDH.S246253] [Medline: 32214821]

77. Mascia D, Rinninella E, Pennacchio NW, Cerrito L, Gasbarrini A. It's how we communicate! Exploring face-to-face versus electronic communication networks in multidisciplinary teams. Health Care Manage Rev 2019 Apr 17:1 [FREE Full text] [doi: 10.1097/HMR.0000000000000246] [Medline: 31008805]

78. Yüce, Adalı E, Kanmaz B. An analysis of YouTube videos as educational resources for dental practitioners to prevent the spread of COVID-19. Ir J Med Sci 2021 Mar;190(1):19-26 [FREE Full text] [doi: 10.1007/s11845-020-02312-5] [Medline: $\underline{32700083}$ ]

79. Bamat NA, Manley BJ, Harer MW, Roland D. Social media for pediatric research: what, who, why, and \#? Pediatr Res 2018 Nov;84(5):597-599 [FREE Full text] [doi: 10.1038/s41390-018-0140-7] [Medline: 30140067]

80. Helm J, Jones RM. Practice paper of the academy of nutrition and dietetics: social media and the dietetics practitioner: opportunities, challenges, and best practices. J Acad Nutr Diet 2016 Nov;116(11):1825-1835. [doi: 10.1016/j.jand.2016.09.003] [Medline: 27788767]

81. Loeb S, Carrick T, Frey C, Titus T. Increasing social media use in urology: 2017 American Urological Association Survey. Eur Urol Focus 2020 May 15;6(3):605-608 [FREE Full text] [doi: 10.1016/j.euf.2019.07.004] [Medline: 31351900]

82. Pizzuti AG, Patel KH, McCreary EK, Heil E, Bland CM, Chinaeke E, et al. Healthcare practitioners' views of social media as an educational resource. PLoS One 2020;15(2):e0228372 [FREE Full text] [doi: 10.1371/journal.pone.0228372] [Medline: $\underline{32027686]}$

83. Borgmann H, DeWitt S, Tsaur I, Haferkamp A, Loeb S. Novel survey disseminated through Twitter supports its utility for networking, disseminating research, advocacy, clinical practice and other professional goals. Can Urol Assoc J 2015;9(9-10):E713-E717 [FREE Full text] [doi: 10.5489/cuaj.3014] [Medline: 26664662]

84. Birnbaum ML, Rizvi AF, Correll CU, Kane JM. Role of social media and the Internet in pathways to care for adolescents and young adults with psychotic disorders and non-psychotic mood disorders. Early Interv Psychiatry 2015 Mar 23;11(4):290-295. [doi: 10.1111/eip.12237] [Medline: 25808317]

85. Tang W, Ren J, Zhang Y. Enabling trusted and privacy-preserving healthcare services in social media health networks. IEEE Trans Multimedia 2019 Mar;21(3):579-590 [FREE Full text] [doi: 10.1109/tmm.2018.2889934] 
86. Benetoli A, Chen TF, Schaefer M, Chaar B, Aslani P. Do pharmacists use social media for patient care? Int J Clin Pharm 2017 Apr;39(2):364-372 [FREE Full text] [doi: 10.1007/s11096-017-0444-4] [Medline: 28299527]

87. Hermansyah A, Sukorini AI, Asmani F, Suwito KA, Rahayu TP. The contemporary role and potential of pharmacist contribution for community health using social media. J Basic Clin Physiol Pharmacol 2019 Dec 04;30(6):1 [FREE Full text] [doi: 10.1515/jbcpp-2019-0329] [Medline: $\underline{\text { 31800395] }}$

88. Senthilkumaran S, Benita F, Balamurugan N, Thirumalaikolundusubramanian P. Social media for health care education-can it make a difference? Am J Emerg Med 2018 Jan;36(1):150-151 [FREE Full text] [doi: 10.1016/j.ajem.2017.07.027] [Medline: 28709715]

89. Liu Q, Liu X, Guo X. The effects of participating in a physician-driven online health community in managing chronic disease: evidence from two natural experiments. MISQ 2020 Jan 01;44(1):391-419 [FREE Full text] [doi: 10.25300/misq/2020/15102]

90. Shen L, Wang S, Chen W, Fu Q, Evans R, Lan F, et al. Understanding the function constitution and influence factors on communication for the wechat official account of top tertiary hospitals in china: cross-sectional study. J Med Internet Res 2019 Dec 09;21(12):e13025 [FREE Full text] [doi: 10.2196/13025] [Medline: $\underline{31815674]}$

91. Peluchette JV, Karl KA, Coustasse A. Physicians, patients, and Facebook: Could you? Would you? Should you? Health Mark Q 2016;33(2):112-126 [FREE Full text] [doi: 10.1080/07359683.2016.1166811] [Medline: 27295007]

92. Kenny P, Johnson IG. Social media use, attitudes, behaviours and perceptions of online professionalism amongst dental students. Br Dent J 2016 Nov 18;221(10):651-655. [doi: 10.1038/sj.bdj.2016.864] [Medline: 27857111]

93. Ahmed W, Bath PA, Sbaffi L, Demartini G. Novel insights into views towards H1N1 during the 2009 Pandemic: a thematic analysis of Twitter data. Health Info Libr J 2019 Mar;36(1):60-72 [FREE Full text] [doi: 10.1111/hir.12247] [Medline: 30663232]

94. Raggatt M, Wright CJC, Carrotte E, Jenkinson R, Mulgrew K, Prichard I, et al. "I aspire to look and feel healthy like the posts convey": engagement with fitness inspiration on social media and perceptions of its influence on health and wellbeing. BMC Public Health 2018 Aug 10;18(1):1002 [FREE Full text] [doi: 10.1186/s12889-018-5930-7] [Medline: 30097034]

95. Gomez-Lopez IN, Clarke P, Hill AB, Romero DM, Goodspeed R, Berrocal VJ, et al. Using social media to identify sources of healthy food in urban neighborhoods. J Urban Health 2017 Jun;94(3):429-436 [FREE Full text] [doi: 10.1007/s11524-017-0154-1] [Medline: 28455606]

96. Lambert M, Chivers P, Farringdon F. In their own words: a qualitative study exploring influences on the food choices of university students. Health Promot J Austr 2019 Jan;30(1):66-75 [FREE Full text] [doi: 10.1002/hpja.180] [Medline: 29892990]

97. Zhu C, Zeng R, Zhang W, Evans R, He R. Pregnancy-related information seeking and sharing in the social media era among expectant mothers: qualitative study. J Med Internet Res 2019 Dec 04;21(12):e13694 [FREE Full text] [doi: 10.2196/13694] [Medline: 31799939]

98. Schwartz B. How often do patients turn to social media for STD second opinions? Contemporary OB/GYN 2019;64(12):18.

99. Wu T, He Z, Zhang D. Impact of communicating with doctors via social media on consumers' e-health literacy and healthy behaviors in China. Inquiry 2020;57:46958020971188 [FREE Full text] [doi: 10.1177/0046958020971188] [Medline: 33238788]

100. Ahmed N, Quinn SC, Hancock GR, Freimuth VS, Jamison A. Social media use and influenza vaccine uptake among White and African American adults. Vaccine 2018 Nov 26;36(49):7556-7561 [FREE Full text] [doi: 10.1016/j.vaccine.2018.10.049] [Medline: 30389192]

101. Tengilimoglu D, Sarp N, Yar CE, Bektaş M, Hidir MN, Korkmaz E. The consumers' social media use in choosing physicians and hospitals: the case study of the province of Izmir. Int J Health Plann Manage 2017 Jan;32(1):19-35. [doi: 10.1002/hpm.2296] [Medline: 26198772]

102. Sagnia PIG, Gharoro EP, Isara AR. Adolescent-parent communication on sexual and reproductive health issues amongst secondary school students in Western Region 1 of The Gambia. Afr J Prim Health Care Fam Med 2020 Nov 04;12(1):e1-e7 [FREE Full text] [doi: 10.4102/phcfm.v12i1.2437] [Medline: 33181882]

103. Reidy C, Klonoff DC, Barnard-Kelly KD. Supporting good intentions with good evidence: how to increase the benefits of diabetes social media. J Diabetes Sci Technol 2019 Sep;13(5):974-978 [FREE Full text] [doi: 10.1177/1932296819850187] [Medline: 31096768 ]

104. Sallam M, Dababseh D, Yaseen A, Al-Haidar A, Taim D, Eid H, et al. COVID-19 misinformation: mere harmless delusions or much more? A knowledge and attitude cross-sectional study among the general public residing in Jordan. PLoS One 2020;15(12):e0243264 [FREE Full text] [doi: 10.1371/journal.pone.0243264] [Medline: 33270783]

105. Crilly P, Jair S, Mahmood Z, Moin Khan A, Munir A, Osei-Bediako I, et al. Public views of different sources of health advice: pharmacists, social media and mobile health applications. Int J Pharm Pract 2019 Mar;27(1):88-95 [FREE Full text] [doi: 10.1111/ijpp.12448] [Medline: 29732649]

106. Cutrona C, Suhr J. Controllability of stressful events and satisfaction with spouse support behaviors. Comm Res 2016 Jun 30;19(2):154-174 [FREE Full text] [doi: 10.1177/009365092019002002] 
107. Naslund JA, Aschbrenner KA, Marsch LA, Bartels SJ. The future of mental health care: peer-to-peer support and social media. Epidemiol Psychiatr Sci 2016 Apr;25(2):113-122 [FREE Full text] [doi: 10.1017/S2045796015001067] [Medline: 26744309]

108. Årsand E, Bradway M, Gabarron E. What are diabetes patients versus health care personnel discussing on social media? J Diabetes Sci Technol 2019 Mar;13(2):198-205 [FREE Full text] [doi: 10.1177/1932296818821649] [Medline: 30636445]

109. Rupert DJ, Gard Read J, Amoozegar JB, Moultrie RR, Taylor OM, O'Donoghue AC, et al. Peer-generated health information: the role of online communities in patient and caregiver health decisions. J Health Commun 2016 Nov;21(11):1187-1197 [FREE Full text] [doi: 10.1080/10810730.2016.1237592] [Medline: 27805496]

110. Xu Y, Burleson B. Effects of sex, culture, and support type on perceptions of spousal social support: an assessment of the "support gap" hypothesis in early marriage. Human Comm Res 2001 Oct;27(4):535-566 [FREE Full text] [doi: 10.1111/j.1468-2958.2001.tb00792.x]

111. Yeo TED, Chu TH. Sharing "sex secrets" on Facebook: a content analysis of youth peer communication and advice exchange on social media about sexual health and intimate relations. J Health Commun 2017 Sep;22(9):753-762 [FREE Full text] [doi: 10.1080/10810730.2017.1347217] [Medline: 28796578]

112. McCarthy R, Byrne G, Brettle A, Choucri L, Ormandy P, Chatwin J. Midwife-moderated social media groups as a validated information source for women during pregnancy. Midwifery 2020 Sep;88:102710. [doi: 10.1016/j.midw.2020.102710] [Medline: $\underline{32485501]}$

113. Shaw RJ, Johnson CM. Health information seeking and social media use on the internet among people with diabetes. Online J Public Health Inform 2011;3(1):3561 [FREE Full text] [doi: 10.5210/ojphi.v3i1.3561] [Medline: 23569602]

114. Prescott J, Rathbone AL, Brown G. Online peer to peer support: qualitative analysis of UK and US open mental health Facebook groups. Digit Health 2020;6:2055207620979209 [FREE Full text] [doi: 10.1177/2055207620979209] [Medline: 33354335]

115. Platt JR, Brady RR. \#BCSM and \#breastcancer: contemporary cancer-specific online social media communities. Breast $\mathrm{J}$ 2020 Apr;26(4):729-733. [doi: 10.1111/tbj.13576] [Medline: $\underline{31493301]}$

116. Byron P, Hunt J. 'That happened to me too': young people's informal knowledge of diverse genders and sexualities. Sex Education 2017 Feb 22;17(3):319-332 [FREE Full text] [doi: 10.1080/14681811.2017.1292899]

117. Zigron S, Bronstein J. "Help is where you find it": the role of weak ties networks as sources of information and support in virtual health communities. J Assoc Inf Sci Technol 2018 Nov 19;70(2):130-139 [FREE Full text] [doi: 10.1002/asi.24106]

118. Chaddha A, Jackson EA, Richardson CR, Franklin BA. Technology to help promote physical activity. Am J Cardiol 2017 Jan 01;119(1):149-152 [FREE Full text] [doi: 10.1016/j.amjcard.2016.09.025] [Medline: 27889045]

119. Lerman B, Lewis S, Lumley M, Grogan G, Hudson C, Johnson E. Teen depression groups on Facebook: a content analysis. J Adolesc Res 2016 Oct 22;32(6):719-741 [FREE Full text] [doi: 10.1177/0743558416673717]

120. Cole L, Kharwa Y, Khumalo N, Reinke J, Karrim S. Caregivers of school-aged children with autism: social media as a source of support. J Child Fam Stud 2017 Aug 31;26(12):3464-3475 [FREE Full text] [doi: 10.1007/s10826-017-0855-9]

121. Manduley A, Mertens A, Plante I, Sultana A. The role of social media in sex education: dispatches from queer, trans, and racialized communities. Feminism Psychol 2018 Feb 08;28(1):152-170 [FREE Full text] [doi: 10.1177/0959353517717751]

122. Clapton-Caputo E, Sweet L, Muller A. A qualitative study of expectations and experiences of women using a social media support group when exclusively expressing breastmilk to feed their infant. Women Birth 2020 Jul 13:1. [doi: 10.1016/j.wombi.2020.06.010] [Medline: 32674991]

123. Pretorius C, Chambers D, Coyle D. Young people's online help-seeking and mental health difficulties: systematic narrative review. J Med Internet Res 2019 Nov 19;21(11):e13873 [FREE Full text] [doi: 10.2196/13873] [Medline: 31742562]

124. Han X, Li B, Qu J, Zhu Q. Weibo friends with benefits for people live with HIV/AIDS? The implications of Weibo use for enacted social support, perceived social support and health outcomes. Soc Sci Med 2018 Aug;211:157-163 [FREE Full text] [doi: 10.1016/j.socscimed.2018.06.016] [Medline: 29940485]

125. Wan Adnan W, Ibrahim N, Haladin N, Wan Fakhruddin W. Illness experience sharing on personal blogs: a case study of malaysian breast cancer survivors. GEMA 2019 Nov 29;19(4):28-47 [FREE Full text] [doi: 10.17576/gema-2019-1904-02]

126. Song J, Xu P, Paradice DB. Health goal attainment of patients with chronic diseases in web-based patient communities: content and survival analysis. J Med Internet Res 2020 Sep 11;22(9):e19895 [FREE Full text] [doi: 10.2196/19895] [Medline: 32915152]

127. Armin J, Johnson T, Hingle M, Giacobbi P, Gordon JS. Development of a multi-behavioral mhealth app for women smokers. J Health Commun 2017 Feb;22(2):153-162. [doi: 10.1080/10810730.2016.1256454] [Medline: 28121240]

128. Kent R. Self-tracking health over time: from the use of instagram to perform optimal health to the protective shield of the digital detox. Soc Media Soc 2020 Sep 18;6(3):205630512094069 [FREE Full text] [doi: 10.1177/2056305120940694]

129. Carter S, Green J, Speed E. Digital technologies and the biomedicalisation of everyday activities: the case of walking and cycling. Sociol Compass 2018 Mar 15;12(4):e12572 [FREE Full text] [doi: 10.1111/soc4.12572]

130. Al Walid M. Data analysis and visualization of continental cancer situation by twitter scraping. IJMECS 2019 Jul 08;11(7):23-31 [FREE Full text] [doi: 10.5815/ijmecs.2019.07.03] 
131. Bhattacharya S, Srinivasan P, Polgreen P. Social media engagement analysis of U.S. Federal health agencies on Facebook. BMC Med Inform Decis Mak 2017 Apr 21;17(1):49 [FREE Full text] [doi: 10.1186/s12911-017-0447-z] [Medline: 28431582]

132. Carlquist E, Lee NE, Shalin SC, Goodman M, Gardner JM. Dermatopathology and social media: improving participation by increasing clarity. Arch Pathol Lab Med 2018 Jan;142(1):11 [FREE Full text] [doi: 10.5858/arpa.2017-0331-LE] [Medline: 29257927]

133. Brandhorst J, Jennings F. Fighting for funding: values advocacy and Planned Parenthood's right-to-life. Public Relations Rev 2016 Nov;42(4):723-733 [FREE Full text] [doi: 10.1016/j.pubrev.2016.06.002]

134. Fergie G, Hunt K, Hilton S. Social media as a space for support: young adults' perspectives on producing and consuming user-generated content about diabetes and mental health. Soc Sci Med 2016 Dec;170:46-54 [FREE Full text] [doi: 10.1016/j.socscimed.2016.10.006] [Medline: 27750067]

135. Huh J, Kwon BC, Kim S, Lee S, Choo J, Kim J, et al. Personas in online health communities. J Biomed Inform 2016 Oct;63:212-225. [doi: 10.1016/j.jbi.2016.08.019] [Medline: 27568913]

136. De Simoni A, Shah AT, Fulton O, Parkinson J, Sheikh A, Panzarasa P, et al. Superusers' engagement in asthma online communities: asynchronous web-based interview study. J Med Internet Res 2020 Jun 23;22(6):e18185 [FREE Full text] [doi: 10.2196/18185] [Medline: 32573463]

137. Zhao Y, Zhu X, Pérez AE, Zhang W, Shi A, Zhang Z, et al. MHealth approach to promote Oral HIV self-testing among men who have sex with men in China: a qualitative description. BMC Public Health 2018 Sep 27;18(1):1146 [FREE Full text] [doi: 10.1186/s12889-018-6046-9] [Medline: 30261856]

138. Condran B, Gahagan J, Isfeld-Kiely H. A scoping review of social media as a platform for multi-level sexual health promotion interventions. Can J Human Sexuality 2017 Apr;26(1):26-37 [FREE Full text] [doi: 10.3138/cjhs.261-a1]

139. Arigo D, Jake-Schoffman DE, Wolin K, Beckjord E, Hekler EB, Pagoto SL. The history and future of digital health in the field of behavioral medicine. J Behav Med 2019 Feb;42(1):67-83. [doi: 10.1007/s10865-018-9966-z] [Medline: 30825090]

140. Garett R, Menacho L, Young SD. Ethical issues in using social media to deliver an HIV prevention intervention: results from the HOPE Peru study. Prev Sci 2017 Feb;18(2):225-232 [FREE Full text] [doi: 10.1007/s11121-016-0739-z] [Medline: 27933425]

141. O'Neill B. Towards an improved understanding of modern health information ecology. Soc Sci Med 2017 Jan;173:108-109 [FREE Full text] [doi: 10.1016/j.socscimed.2016.12.003] [Medline: 27951460]

142. Perski O, Blandford A, Ubhi HK, West R, Michie S. Smokers' and drinkers' choice of smartphone applications and expectations of engagement: a think aloud and interview study. BMC Med Inform Decis Mak 2017 Dec 28;17(1):25 [FREE Full text] [doi: 10.1186/s12911-017-0422-8] [Medline: 28241759]

143. Gow J, Moffatt C, Blackport J. Participation in patient support forums may put rare disease patient data at risk of re-identification. Orphanet J Rare Dis 2020 Aug 31;15(1):226 [FREE Full text] [doi: 10.1186/s13023-020-01497-3] [Medline: 32867839]

144. Wang S, Ding S, Xiong L. A new system for surveillance and digital contact tracing for COVID-19: spatiotemporal reporting over network and GPS. JMIR Mhealth Uhealth 2020 Jun 10;8(6):e19457 [FREE Full text] [doi: 10.2196/19457] [Medline: 32499212]

145. Hennessy CM, Smith CF, Greener S, Ferns G. Social media guidelines: a review for health professionals and faculty members. Clin Teach 2019 Oct;16(5):442-447. [doi: 10.1111/tct.13033] [Medline: $\underline{31144449]}$

146. Bender JL, Cyr AB, Arbuckle L, Ferris LE. Ethics and privacy implications of using the internet and social media to recruit participants for health research: A privacy-by-design framework for online recruitment. J Med Internet Res 2017;19(4):e104 [FREE Full text] [doi: 10.2196/jmir.7029] [Medline: 28385682]

\section{Abbreviations \\ LGBTQIA+: lesbian, gay, bisexual, transgender, queer, intersex, asexual \\ PRISMA: Preferred Reporting Items for Systematic Reviews and Meta-analyses}

Edited by G Eysenbach; submitted 22.01.20; peer-reviewed by H Korda, JR Bautista; comments to author 23.09.20; revised version
received 29.01.21; accepted 11.04.21; published 12.05.21
Please cite as:
Chen J, Wang Y
Social Media Use for Health Purposes: Systematic Review
J Med Internet Res 2021;23(5):e17917
URL: $\underline{\text { https://www.jmir.org/2021/5/e17917 }}$
doi: $10.2196 / 17917$
PMID:


(CJunhan Chen, Yuan Wang. Originally published in the Journal of Medical Internet Research (https://www.jmir.org), 12.05.2021. This is an open-access article distributed under the terms of the Creative Commons Attribution License (https://creativecommons.org/licenses/by/4.0/), which permits unrestricted use, distribution, and reproduction in any medium, provided the original work, first published in the Journal of Medical Internet Research, is properly cited. The complete bibliographic information, a link to the original publication on https://www.jmir.org/, as well as this copyright and license information must be included. 